\title{
Case Study: Horseplay In The Workplace
}

John J. Lucas, Purdue University Calumet, USA

\begin{abstract}
This HRM case examines the concept of "Horseplay" in the workplace as clerical employees were playing "popcorn basketball." This case is based upon an actual event that occurred in a business unit of a Fortune 500 company. The case study can be used for any undergraduate or graduate level human resource management class.
\end{abstract}

Keywords: Horseplay; Discipline for Horseplay

\section{INTRODUCTION}

(๑)

ne afternoon, two clerical employees, who were members of the International Brotherhood of Electrical Workers (IBEW), observed a management employee sleeping in his chair with his mouth wide opened. The employees decided to play "popcorn basketball" by throwing pieces of popcorn at the wide opened mouth of the management employee. In essence, they were using the management employee's mouth as a basketball rim. After a few attempts, one bargaining unit employee was successful and landed a couple pieces of popcorn directly into the mouth of the sleeping management employee. The management employee started choking on the pieces of popcorn that had lodged in his mouth. The two bargaining employees were laughing profusely at the reaction of the startled employee. The management employee, still somewhat dazed, started screaming at the two employees with abusive and foul language. With such a loud commotion in the office, the department head came in and had to intervene to end this disturbance in the workplace.

\section{UNION'S POSITION}

Management employees serve as role models in the workplace. If the management employee was not sleeping, with his mouth wide opened, this event would have not occurred. Additionally, the management employee screamed loudly and used abusive language towards the clerical employees when he awoke from his afternoon nap during working hours. Clearly, this is just another glaring case of the abuses that our union members encounter at the company.

\section{COMPANY'S POSITION}

The company agreed that management employees must serve as "role models" in the workplace. Therefore, the management employee should have not been sleeping nor used any type of abusive language towards the clerical employees. His actions were totally unacceptable and he will be disciplined accordingly. However, the fact remained that the clerical employees were "horseplaying" during working hours and must be disciplined for their inappropriate actions. The company has a zero tolerance for "horseplay" in the workplace, as described in the company's handbook that is given to every employee.

\section{QUESTIONS FOR THE CASE STUDY}

1. What is the appropriate discipline for the management employee based upon his actions?

2. What is the proper discipline, if any, for the clerical employees for "horseplay" in the workplace?

3. What possible recourse, if any, is available to the clerical employees, if they deemed the discipline as excessive?

4. What other course of action can the company undertake to reinforce that there is a zero tolerance for "horseplay in the workplace?" 


\section{INSTRUCTOR'S NOTES}

This case provides an interesting examination of the concept of "horseplay in the workplace" and the appropriate course of action if it should occur in the workplace. The case can be used in any undergraduate or graduate level human resource management class. It is designed to be conducted as a group assignment or general class discussion within one class hour.

\section{AUTHOR INFORMATION}

John J. Lucas, Purdue University Calumet, Dr. Lucas is a Professor at Purdue University Calumet and teaches a variety of human resource management courses. He earned his Master of Science in Industrial Relations (MSIR) and $\mathrm{Ph} . \mathrm{D}$. degrees from Loyola University Chicago. His research interests are in the areas of labor relations, employee benefits, and health education. He is also a graduate of Purdue University Calumet. 